DOI: https://doi.org/10.24127/ajpm.v10i4.4169

\title{
DESIGN OF ETHNOMATHEMATICS MOBILE MODULE TO FACILITATE STUDENTS MATHEMATICAL THINKING ABILITY
}

\author{
Henry Suryo Bintoro ${ }^{1}$, Ratri Rahayu ${ }^{2 *}$, Alif Catur Murti ${ }^{3}$ \\ ${ }^{1,2 * 3}$ Universitas Muria Kudus, Kudus, Indonesia \\ * Corresponding author. Jl. Lingkar Utara UMK, Gondangmanis, 59327, Kudus, Indonesia \\ E-mail: henry.suryo@umk.ac.id ${ }^{l)}$ \\ ratri.rahayu@umk.ac.id $^{2 *)}$ \\ alif.catur@umk.ac.id $^{3)}$
}

Received 27 August 2021; Received in revised form 17 November 2021; Accepted 21 December 2021

\begin{abstract}
The ability to think mathematically is very important for students to solve problems in everyday life. However, in reality, many students cannot find concepts, reason, problem-solving, communication, and connect mathematics to other sciences. This happens because students are not able to understand abstract mathematics. Teaching materials are needed in the form of applications on the device so that they are attractive to students. The ethnomathematics mobile module is a teaching material that contains mathematical material that is brought closer to everyday life through ethnomathematical learning. This study uses research and development (R\&D) methods with the Borg \& Gall model which is adapted from Sugiono's development model. The data of this study were obtained from a validation questionnaire of material experts and media experts. The type of data produced is qualitative data which is analyzed with assessment criteria guidelines to determine product quality. The purpose of this study is to obtain an ethnomathematics mobile module design to facilitate valid mathematical thinking skills. Based on the results of the assessment from the validator, the average value of the ethnomathematics mobile module material validity test was 3.76 (very valid) by material experts and the validity of the ethnomathematics mobile module media was 3.80 (very valid) by media experts. These results indicate that the ethnomathematics mobile module that was developed is valid or feasible to use.
\end{abstract}

Keywords: Ethnomathematics mobile module; mathematical thinking skills; validity.

\begin{abstract}
Abstrak
Kemampuan berpikir matematis sangat penting dimiliki oleh siswa untuk menyelesaikan masalah dalam kehidupan sehari-hari. Namun, kenyataannya siswa banyak siswa yang belum memiliki kemampuan menemukan konsep, bernalar, pemecahan masalah, komunikasi, dan mengkoneksikan matematika ke dalam ilmu yang lain. Hal ini terjadi karena siswa tidak mampu memahami matematika yang bersifat abstrak. Diperlukan bahan ajar yang berbentuk aplikasi di gawai sehingga menarik bagi siswa. Ethnomathematics mobile modul merupakan bahan ajar yang berisi materi matematika yang didekatkan dengan kehidupan sehari-hari melalui pembelajaran etnomatematika. Penelitian ini menggunakan metode penelitian dan pengembangan $(R \& D)$ dengan model Borg \& Gall yang diadaptasi dari model pengembangan Sugiono. Data penelitian ini diperoleh dari angket validasi ahli materi dan ahli media. Jenis data yang dihasilkan adalah data kualitatif yang dianalisis dengan pedoman kriteria penilaian untuk menentukan kualitas produk. Tujuan dari penelitian ini adalah untuk mendapatkan rancangan modul mobile ethnomathematics untuk memfasilitasi keterampilan berpikir matematis yang valid. Berdasarkan hasil penilaian dari validator didapatkan rata-rata nilai uji kelayakan materi ethnomathematics mobile modul sebesar 3,76 (sangat valid) oleh ahli materi dan kelayakan media ethnomathematics mobile modul sebesar 3,80 (sangat valid) oleh ahli media. Hasil ini menunjukkan bahwa bahan ajar ethnomathematics mobile modul yang dikembangkan dinyatakan valid atau layak untuk digunakan.
\end{abstract}

Kata kunci: Ethnomathematics mobile modul; kelayakan; kemampuan berpikir matematis.

This is an open access article under the Creative Commons Attribution 4.0 International License 
DOI: https://doi.org/10.24127/ajpm.v10i4.4169

\section{INTRODUCTION}

The 21st-century competency skills consist of critical thinking and problem solving (critical thinking and problem-solving), creativity (creativity), communication skills (communication skills), and the ability to work collaboratively (the ability to work together). One of the critical thinking skills in which there is the ability to think mathematically so that the ability to think mathematically has an important role in everyday life. In line with (Bintoro \& Sumaji, 2021)(Princess et al., 2020)(Ucisaputri et al., 2020) that the ability to think mathematically is very important to be developed in learning because students think systematically, analyze problems well, express opinions, and make decisions.

The condition of mathematical thinking ability is still relatively low. This is shown by the average national exam result in Indonesia is 39.23 (Akhyar, 2019). Students still have difficulty solving problems in everyday life. Mathematical thinking skills need to be improved in the learning process to understand a problem (Putri et al., 2020). The importance of mathematical thinking skills for students because it has an impact on students to adapt to various challenges in the future (Umam \& Azhar, 2021).

In the current state of the COVID19 pandemic, technology-based teaching materials are needed that can be used by students anywhere and play a role in improving mathematical thinking skills. Android-based teaching materials are an alternative as a learning tool. Research result (Sincuba \& John, 2017)(Bano et al., 2018) show that mobile learning-based teaching materials are effective and very useful for learning mathematics. Mobile learning is the use of technology in the learning process using a tablet, $\mathrm{PC}$, or smartphone. Online mobile-based learning Provides opportunities for students to learn anytime and anywhere (Darmaji et al., 2019).

Mobile-based teaching materials need to be developed to improve mathematical thinking skills. The ability to think mathematically is one of the competency skills of the 21 st century. The ability to think mathematically has an important role in solving problems in everyday life. Research result (Jihad et al., 2018)(Rasiman. \& Pramasdyahsari, 2014) shows the product of the development of mobile learning teaching materials affects improving mathematical understanding so that teachers are required to be able to use Android-based mobile learning for learning mathematics.

To make teaching materials more interesting, they are associated with the cultural context around them. The culture around is very close to students, meaning that linking culture with mathematics material makes learning more interesting. In addition to making it interesting, students also have extensive information related to the culture around them so that they will love and appreciate their own culture more. Ethno-mathematical learning facilitates students to learn by observing and analyzing social activities, local advantages, and historical sites related to mathematical concepts (Rahayu et al., 2018). Research result (Supiyati et al., 2019)(Hartinah et al., 2019) shows that mathematics learning is more interesting and meaningful for students when it is associated with the surrounding cultural context.

The reality on the ground shows that so far, teachers have not used technology-based teaching materials with the theme of regional culture to 
learn mathematics. In addition, 21stcentury students also prefer to play with gadgets than read printed books. Therefore, we need a virtual mathematics textbook that contains elements of culture and can be read through devices.

Based on the problems described, this study aims to develop a valid ethnomathematics mobile module. The first step produce a valid mobile module. The urgency of this research is limited to the ethnomathematics mobile module which is valid to be used to improve the mathematical thinking ability of junior high school students. Possession of good mathematical thinking skills is needed by students to face real-life problems that are increasingly challenging in the $21 \mathrm{st}$ century.

\section{METHODS}

This type of research is $R \& D$ (Research and Development) with the development model of Borg \& Gall. The development stages include preliminary studies, planning, testing and validation, and dissemination. In this study, only up to the third stage, namely trial and validation.

Activities in the preliminary study are used to obtain data related to problems that occur during learning. The planning stage includes planning and developing ethnomathematics mobile module teaching materials.

The next stage is testing and validation of the developed teaching materials. At this stage, it is only limited to obtaining validation from material experts and media experts so that they can produce an initial draft of mobile ethnomathematics teaching materials that are ready to be tested.

The research instrument used to collect data is the validation sheet for the ethnomathematics mobile module teaching materials. The data collection method in this study uses a validator assessment of the ethnomathematics mobile module teaching materials developed. The data obtained were then analyzed descriptively by determining the average score of the validator's assessment.

Validation assessment using a questionnaire instrument compiled use Likert scale. Likert scale questionnaire consists of 4 criteria, namely criteria 4: very good; 3: good; 2: enough; 1 : less. After obtaining the total score then dividing the score obtained by the number of questions, then the next step is interpreted using the product validity criteria based on Table 1.

Table 1. Range of validity categories

\begin{tabular}{cc}
\hline Validity $(\mathbf{X})$ & Category \\
\hline $1,00<X \leq 1,99$ & Invalid \\
$1,99<X \leq 2,99$ & Less Valid \\
$2,99<X \leq 3,49$ & Valid \\
$3,49<X \leq 4,00$ & Very Valid \\
\hline
\end{tabular}

The teaching materials ethnomathematics mobile module is called valid if each teaching materials fall into the valid or very valid category.

\section{RESULTS AND DISCUSSION}

Based on the results of the preliminary study questionnaire, it showed that $75 \%$ of students needed mobile application media, $75 \%$ of students were interested in learning mathematics and related to culture (ethnomathematics), and $74 \%$ of students were interested in learning sacred culture. This shows that to develop students' mathematical thinking skills, learning media that are packaged in mobile (electronic) are needed. The media that students need is media based 
on their cultural ethnomathematics, namely the culture of the Kudus district.

The ethnomathematics component of the mobile module is divided into 3 main parts, namely the introduction, the core, and the end. The introductory section includes the initial login page, instructions for use, and information regarding basic competencies. The core section contains the main learning activities consisting of several learning activities that require students to achieve competence in each learning activity consisting of material. The last part contains motivational sentences

The content of the ethnomathematics mobile module contains indicators, basic competencies, learning objectives that will be achieved by students in the learning process of flat-sided building materials. Each learning activity contains ASEP (apperception), JAYA (cultural bridge), SITI (material description), EDI (selfevaluation).

Results development the initial product is teaching materials in the form of an ethnomathematics mobile module application which was then tested for validation by 4 experts, namely material expert validation and media expert validation. Material expert validator Mathematics class VII has as many as 2 people and media expert validators in the field of learning media as many as 2 people. The recapitulation of expert validation results material and media expert is shown in Table 2.

Table 2. Recapitulation of validation results

\begin{tabular}{ccc}
\hline $\begin{array}{c}\text { Expert } \\
\text { Validation }\end{array}$ & $\begin{array}{c}\text { Average } \\
\text { Score }\end{array}$ & Category \\
\hline Material & 3.76 & Very Valid \\
Media & 3.80 & Very Valid \\
\hline Average & $\mathbf{3 . 7 8}$ & Very Valid \\
\hline
\end{tabular}

Based on the validation results shown in Table 2, both assessment results are included in the valid criteria. Obtained an average score of 3.76 on the assessment of material experts, and an average score of 3.80 on the assessment of media experts. The total average score obtained is 3.78 and is included in the category very valid. The following is an explanation of each expert's assessment as follows.

The material expert assessment includes an assessment of the content and language in the material teaching materials ethnomathematics mobile module. The results of the assessments of 2 material expert validators containing content and language indicators are presented in Table 3.

Table 3. Recapitulation of material expert assessment results

\begin{tabular}{cccc}
\hline Validator & Indicator & $\begin{array}{c}\text { Average } \\
\text { Score }\end{array}$ & Category \\
\hline \multirow{2}{*}{1} & Contents & 4.00 & Very Valid \\
& Language & 3.40 & Valid \\
& Contents & 3.71 & Very Valid \\
& Language & 3.70 & Very Valid \\
\hline \multicolumn{2}{c}{ Average } & $\mathbf{3 . 7 6}$ & Very Valid \\
\hline
\end{tabular}

Based on Table 3, the results of the material expert's assessment on the content indicator obtained the average score for the first validator is 4 and the average score for the second validator is 3.71 with all criteria very valid. The data shows that the content of the ethnomathematics mobile module is by material with basic competencies. The material has been prepared in full, broadly, and by the basic competencies contained in the curriculum.

The two validators stated that the material was completely structured, the material was presented in a flexible and easy-to-understand manner, the material was organized into a single unit, the material was arranged, the content of the material was solid, and the material 
contained accurate examples and cases. Both validators stated the use of problem illustrations and the use of pictures related to everyday life is good.

Ethnomathematical content on material related to the culture in Kudus. The two validators state the material and questions in the application ethnomathematics mobile module it is by the cultural content in Kudus and added to the culture that is developing at this time.

Teaching materials in the form of an ethnomathematics mobile module application that aims to improve the mathematical thinking skills of junior high school students. The two validators stated that the material and discussion of questions in the application could help students in developing their mathematical thinking skills.

Assessment on linguistic indicators obtained a score of 3.40 for the first validator and 3.70 for the second validator with very valid criteria. The material expert revealed that this application uses effective sentences, the terms used are standard, and the sentence structure is correct. The two validators stated that the language used was communicative so that it could motivate students to learn. They stated that the language in the application was by the level of students' intellectual and emotional development. The first and second validators revealed that the spelling used was correct, consistent in the use of spelling, and enhanced spelling.

The validator provides suggestions for this application, namely formative and summative assessments should use questions with a cultural context even though they are in the form of multiple-choice entries and descriptions. The following is an excerpt of an image from the application from the beginning and after the repair. Figure 1 shows the initial view before being revised and Figure 2 shows the view after being revised by adding cultural elements that are around.

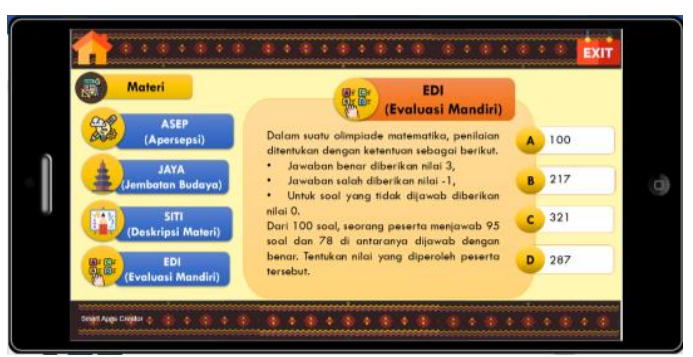

Figure 1. Excerpts of the initial application image

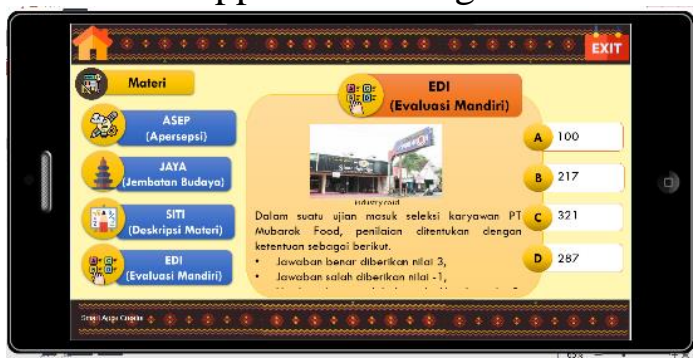

Figure 2. Excerpts of Application Images After Material Improvements

Figure 1 shows an excerpt from the display of the question application that does not have a cultural context. Figure 2 shows that the application has been revised with questions that have a cultural context. This is done because questions with a cultural context will motivate me to read and understand them.

On the assessment of media experts in the form of a questionnaire compiled based on four indicators, namely: (1) navigation; (2) convenience; writing; and (4) display. The media expert validators in this study consisted of 2 people who were experts in the field of learning media. The results of the media expert's assessment can be seen in Table 4. 
DOI: https://doi.org/10.24127/ajpm.v10i4.4169

Table 4. Recapitulation of media expert assessment results

\begin{tabular}{clcc}
\hline Validator & Indicator & $\begin{array}{c}\text { Average } \\
\text { Score }\end{array}$ & Category \\
\hline 1 & Navigation & 4.00 & Very Valid \\
& Convenience & 3.80 & Very Valid \\
& Writing & 4.00 & Very Valid \\
& Appearance & 3.80 & Very Valid \\
2 & Navigation & 4.00 & Very Valid \\
& Convenience & 3.60 & Very Valid \\
& Writing & 3.80 & Very Valid \\
& Appearance & 3.60 & Very Valid \\
\hline \multicolumn{2}{c}{ Average } & $\mathbf{3 . 8}$ & Very Valid \\
\hline
\end{tabular}

Based on Table 4, the results of the media expert's assessment of all indicators have very valid criteria. The data show that the ethnomathematics mobile module application in using the navigation is correct and all useful. This application is also easy to operate, easy to understand the language, easy to run, and easy to provide feedback to students.

The two validators revealed aspects of easy-to-read writing, quality text, quality teaching materials, clear font colors, clear fonts, and clear font sizes. In the aspect of the display, it is appropriate, the image layout is clear, the content placement is clear, the use of the right theme, the quality design display, and the colors and backgrounds are appropriate.

The validator provides several suggestions regarding the ethnomathematics mobile module application, namely, they provide suggestions that it is necessary to add a discussion of the results of student answers for checking. The following is an excerpt of the image of the application after the repair. Figure 3 shows application improvements to make the discussion more accessible.

Figure 3 shows the improvement of the validator's suggestion, namely adding a discussion for all questions and the discussion can be accessed easily by students. It is intended that students can check the answer is correct or not. If the answer is not correct, students can study independently the answer to the question.

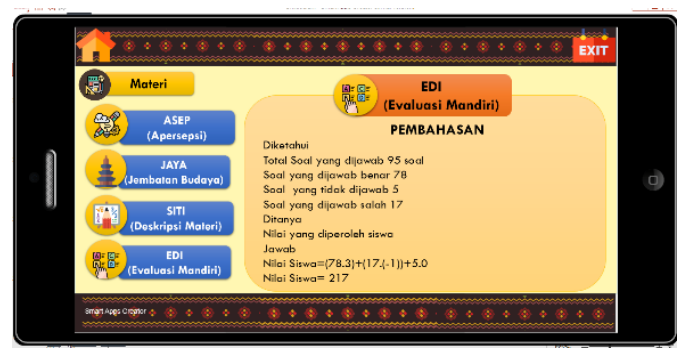

Figure 3. Excerpts of application images after media repair

The validator also advises that the selection of an enlarged image or perhaps a description that focuses on the specific informational message of the culture being raised as context. The goal is to give focus to application users.

Teaching materials have an important role in the learning process. The development of technology that is growing, then teaching materials technology-based learning has the greatest benefit for increasing student understanding. Research result (Abd. Syakur et al., 2020)(Wijaya et al., 2020)(Chotimah et al., 2018) shows that mathematical thinking skills can be improved with the help of teaching materials technology-based. These teaching materials increase students' learning motivation so that students easily understand the material presented. In line with (Sahronih et al., 2019)(Puspitarini \& Hanif, 2019) state that teaching materials technologybased helps increase learning motivation so that students' mathematical thinking skills are increased.

Teaching materials need to be developed because it is one of the factors that determine the success of 
learning mathematics (Widodo \& Wahyudin, 2018). During the COVID19 pandemic, it is necessary to develop technology-based teaching materials, especially Android. This is in line with several studies (Siahaan et al., 2021)(Cahyana et al., 2018)(Saputra et al., 2018).

The results of other research related to mobile applications also need to be developed during the COVID-19 pandemic because it will make it easier to use and make it easier to understand the material. This is in line with (Liliarti \& Kuswanto, 2018)(Dasilva et al., 2019)(Mabruri et al., 2019) teaching materials mobile-based can increase student motivation and ability. 21stcentury skills competencies require students to be skilled at using teaching materials technology-based (Aprilia et al., 2021)(Suprianto et al., 2019). One of the 21st-century skill competencies is the ability to think mathematically teaching materials that are developed based on technology, the students' mathematical thinking ability will increase.

Teaching materials should be supported by a cultural context so that apart from being technology-based, the cultural context is very close to students. The closeness of the cultural context to students makes the content in teaching materials more interesting. Research result (Pujiastuti et al., 2020) show teaching materials based on technology and local wisdom can improve mathematical thinking skills. The results of this study are in line with the results of this study that the application of ethnomathematics mobile module suitable to be used to improve mathematical thinking skills. The feasibility is seen from the application based on technology according to the development of 21st-century competencies and based on culture to increase students' interest and motivation to learn. The development of teaching materials based on ethnomathematics has a positive influence on the cultivation of the character of students who have a noble culture (Ayuningtyas \& Setiana, 2019).

Teaching materials ethnomathematics mobile module its feasibility has been tested because it has met the valid criteria so that it can be used for the process of learning mathematics in junior high school students. Teaching materials in the form of this application contain material, questions, and discussions that are related to the cultural context so that they can be easily recognized and understood by students. Teaching materials in the form of this application can be used as an alternative teaching material that can overcome students' difficulties in understanding mathematical material. Teaching materials ethnomathematics mobile module developed can be used as a teacher's reference in the technologybased mathematics learning process and in particular to improve the character of a noble culture.

Valid ethnomathematics mobile module teaching materials are a good start for obtaining media that can improve mathematical thinking skills. This media can improve mathematical thinking skills because it contains content (1) ASEP (Apperception) which provides the initial basis for students to learn new material that will be delivered by the teacher, thus apperception can provide convenience for students in the learning process, (2) JAYA ( Bridge of Culture) namely the introduction of culture as outlined in the form of this story helps students recognize and increase their love for a culture so that 
learning is more interesting, (3) SITI (Material Description) is a description of the material presented systematically accompanied by interesting illustrations it adds to the interest of students in learning the material, and (4) EDI (SelfEvaluation) contains evaluations to measure students' mathematical thinking ability which contains HOTS questions which will determine the level of mastery of learning materials. This activity aims to enable students to evaluate themselves.

\section{CONCLUSIONS AND SUGGESTIONS}

This research develops teaching materials in the form of applications ethnomathematics mobile module based on ethnomathematics. The assessment results from the validator show teaching materials ethnomathematics mobile module is very valid and worth using so that it can be used for the learning process in the classroom, especially for junior high school students. These teaching materials help students to understand mathematical concepts associated with cultural contexts that students can easily identify. Cultural and historic objects will certainly provide an introduction and understanding to students about the culture that exists in the surrounding environment so that they can have a positive influence on the cultivation of the character of students who have a noble culture. In addition, with the material, sample questions, practice questions, and discussions, students' mathematical thinking skills become more developed.

Teaching materials in the form of an ethnomathematics mobile module application can be used as a teacher reference in the mathematics learning process in the classroom. In the learning process, the teacher should introduce the surrounding cultural context to increase students' learning motivation and cultivate noble character. For further researchers, they can develop an ethnomathematics mobile module using the culture around the researcher and improve other mathematical abilities.

\section{ACKNOWLEDGMENT}

We would like to thank various parties who have assisted in the implementation of this research. First, we would like to thank DRPM the Ministry of Research Technology and Higher Education, Indonesia which has provided a grant for Higher Education Applied Research. Second, we would like to express our gratitude to the Rector and LPPM of Universitas Muria Kudus who have facilitated this research so that it can run according to the provisions. Furthermore, I would like to thank the principal, teachers, and students of SMP 1 Kudus and SMP 1 Dawe who have participated in this research. We hope that this research can be useful for various parties involved and the improvement of ethnomathematics learning in Indonesia.

\section{REFERENCES}

Abd. Syakur, Sugirin, \& Widiarni. (2020). The Effectiveness of English Learning Media through Google Classroom in Higher Education. Britain International of Linguistics Arts and Education (BIoLAE) Journal, 2(1), 475-483. https://doi.org/10.33258/biolae.v2 i1.218

Akhyar, M. K. (2019). Hasil UN buruk HOTS yang salah, Benarkah?: Analisis HOTS pada Soal UNBK terhadap hasil UN Matematika SMA di Indonesia. Factor $M$, 1(2), 143-159. https://doi.org/10.30762/f_m.v1i2. 
DOI: https://doi.org/10.24127/ajpm.v10i4.4169

1518

Aprilia, E., Pujiastuti, H., \& Rafianti, I. (2021). Development of Mathematics Learning Media Using STEM Approach on Linear Programming MateriaL. Kreano: Jurnal Matematika KreatifInovatif, 12(1), 164-177.

Ayuningtyas, A. D., \& Setiana, D. S. (2019). Pengembangan Bahan Ajar Matematika Berbasis Etnomatematika Kraton Yogyakarta. AKSIOMA: Jurnal Program Studi Pendidikan Matematika Volume, 8(1), 11-19.

Bano, M., Zowghi, D., Kearney, M., Schuck, S., \& Aubusson, P. (2018). Mobile learning for science and mathematics school education: A systematic review of empirical evidence. Computers and Education, 121(February 2017), 30-58. https://doi.org/10.1016/j.compedu .2018 .02 .006

Bintoro, H. S., \& Sumaji. (2021). Proses Berpikir Spasial Ditinjau dari Kecerdasan Intrapersonal Mahasiswa Pendidikan Matematika. AKSIOMA: Jurnal Program Studi Pendidikan Matematika, 10(2), 1074-1087.

Cahyana, U., Paristiowati, M., \& Fauziyah, S. (2018). Development of Android-Based Mobile learning media on Atomic Structure and Periodic Table. IOP Conference Series: Materials Science and Engineering, 434(1). https://doi.org/10.1088/1757899X/434/1/012095

Chotimah, S., Bernard, M., \& Wulandari, S. M. (2018). Contextual approach using VBA learning media to improve students' mathematical displacement and disposition ability. Journal of Physics: Conference Series, 948(1). https://doi.org/10.1088/17426596/948/1/012025

Darmaji, Kurniawan, D. A., Astalini, Lumbantoruan, A., \& Samosir, S. C. (2019). Mobile learning in higher education for the industrial revolution 4.0: Perception and response of physics practicum. International Journal of Interactive Mobile Technologies, 13(9), 4-20. https://doi.org/10.3991/ijim.v13i0 9.10948

Dasilva, B. E., Ardiyati, T. K., Suparno, Sukardiyono, Eveline, E., Utami, T., \& Ferty, Z. N. (2019). Development of Android-based Interactive Physics Mobile Learning Media (IPMLM) with scaffolding learning approach to improve HOTS of high school students. Journal for the Education of Gifted Young Scientists, 7(3), 659-681. https://doi.org/10.17478/jegys.610 377

Hartinah, S., Suherman, S., Syazali, M., Efendi, H., Junaidi, R., Jermsittiparsert, K., \& Umam, R. (2019). Probing-prompting based on ethnomathematics learning model: The effect on mathematical communication skills. Journal for the Education of Gifted Young Scientists, 7(4), 799-814.

https://doi.org/10.17478/jegys.574 275

Jihad, A., Susilawati, W., \& Sobarningsih, N. (2018). Improving mathematical understanding ability student through study of mobile learning mathematics base on the Android. IOP Conference Series: Materials 
DOI: https://doi.org/10.24127/ajpm.v10i4.4169

Science and Engineering, 434(1). https://doi.org/10.1088/1757899X/434/1/012008

Liliarti, N., \& Kuswanto, H. (2018). Improving the competence of diagrammatic and argumentative representation in physics through android-based mobile learning application. International Journal of Instruction, 11(3), 106-122. https://doi.org/10.12973/iji.2018.1 $138 \mathrm{a}$

Mabruri, H., Ahmadi, F., \& Suminar, T. (2019). The Development of Science Mobile Learning Media to Improve Primary Students Learning Achievements. Journal of Primary Education, 8(1), 108116.

Pujiastuti, H., Utami, R. R., \& Haryadi, R. (2020). The development of interactive mathematics learning media based on local wisdom and 21st century skills: Social arithmetic concept. Journal of Physics: Conference Series, 1521(3).

https://doi.org/10.1088/17426596/1521/3/032019

Puspitarini, Y. D., \& Hanif, M. (2019). Using Learning Media to Increase Learning Motivation in Elementary School. Anatolian Journal of Education, 4(2), 5360.

https://doi.org/10.29333/aje.2019. $426 a$

Putri, A., Sumardani, D., Rahayu, W., \& Hajizah, M. N. (2020). Kemampuan Berpikir Kritis Matematis Menggunakan Model Generative Learning dan Connecting, Organizing, Reflecting, Extending (CORE). AKSIOMA: Jurnal Program Studi Pendidikan Matematika, 9(1), 108-117.
Rahayu, R., Ulya, H., . K., . I., \& Kurniasih, N. (2018). Collaborative Assessment Using QR-Code on Ethno-mathematics Learning for Pre-Service Teacher. International Journal of Engineering \& Technology, 7(2.13), 413. https://doi.org/10.14419/ijet.v7i2. 13.16934

Rasiman., \& Pramasdyahsari, A. S. (2014). Development of Mathematics Learning Media. International Journal of Education and Research, 2(11), 535-544.

http://eprints.upgris.ac.id/349/

Sahronih, S., Purwanto, A., \& Sumantri, M. S. (2019). The effect of interactive learning media on students' science learning outcomes. ACM International Conference Proceeding Series, Part F1483, 20-24. https://doi.org/10.1145/3323771.3 323797

Saputra, M., Abidin, T. F., Ansari, B. I., \& Hidayat, M. (2018). The feasibility of an Android-based pocketbook as mathematics learning media in senior high school. Journal of Physics: Conference Series, 1088. https://doi.org/10.1088/17426596/1088/1/012056

Siahaan, K. W. A., Manurung, H. M., \& Siahaan, M. M. (2021). AndroidBased Learning Media Development Strategies During Pandemic Times To Improve Student Science Literature. International Journal of Education and Humanities, 1(1), 34-42.

Sincuba, M. C., \& John, M. (2017). An Exploration of Learners' Attitudes towards Mobile Learning 
DOI: https://doi.org/10.24127/ajpm.v10i4.4169

Technology-Based Instruction Module and its Use in Mathematics Education. International Electronic Journal of Mathematics Education, 12(3), 845-858.

http://www.iejme.com/download/ an-exploration-of-learnersattitudes-towards-mobilelearning-technology-basedinstruction-module-and.pdf

Supiyati, S., Hanum, F., \& Jailani. (2019). Ethnomathematics in sasaknese architecture. Journal on Mathematics Education, 10(1), 47-57.

https://doi.org/10.22342/jme.10.1. 5383.47-58

Suprianto, A., Ahmadi, F., \& Suminar, T. (2019). The Development of Mathematics Mobile Learning Media to Improve Students' Autonomous and Learning Outcomes. Journal of Primary Education, 8(1), 84-91.

Ucisaputri, N., Nurhayati, N., \& Pagiling, S. L. (2020). Pengaruh Pendekatan Saintifik Terhadap Kemampuan Berpikir Kritis Matematis Pada Siswa Smp Negeri 2 Merauke. AKSIOMA: Jurnal Program Studi Pendidikan Matematika, 9(3), 789. https://doi.org/10.24127/ajpm.v9i 3.2919

Umam, K., \& Azhar, E. (2021). Bagaimana Bahan Ajar Berbasis Website Membantu Meningkatkan Kemampuan Berpikir Kritis Matematis Siswa? AKSIOMA: Jurnal Program Studi Pendidikan Matematika, 10(3), 1493-1506.

Widodo, S., \& Wahyudin. (2018). Selection of Learning Media Mathematics for Junior School Students. Turkish Online Journal of Educational Technology TOJET, 17(1), 154-160. http://www.tojet.net/

Wijaya, T. T., Ying, Z., \& Cunhua, L. (2020). Using Vba Learning Media To Improve Students '. Journal On Education, 02(02), 245-254. 